\title{
New chelating resin for preconcentration and determination of molybdenum by inductive couple plasma atomic emission spectroscopy
}

\author{
${ }^{1}$ H. Sid Kalal; ${ }^{2}$ H. Ahmad Panahi; ${ }^{2}$ N. Framarzi; ${ }^{3}$ E. Moniri; ${ }^{4}$ A. Naeemy; \\ ${ }^{5}$ H. Hoveidi; ${ }^{1}$ A. Abhari \\ ${ }^{1}$ Department of Waste Management, Nuclear Science and Technology Institute, AEOI, Tehran, Iran \\ ${ }^{2}$ Department of Chemistry, Islamic Azad University, Central Tehran Branch,Tehran, Iran \\ ${ }^{3}$ Department of Chemistry, Islamic Azad University, Pishva Branch,Varamin, Iran \\ ${ }^{4}$ Department of Chemistry, Faculty of Science, K.N. Toosi University of Technology, Tehran, Iran \\ ${ }^{5}$ Department of Environmental Management, Faculty of the Environment, University of Tehran, Tehran, Iran \\ Received 20 October 2010; revised 15 January 2011; accepted 18 April 2011; available online 1 June 2011

\begin{abstract}
A chelating resin is prepared by condensation polymerization of aniline with formaldehyde and characterized by Fourier transform infrared spectrometer, elemental analysis and thermogravimetric analysis and studied for the preconcentration and determination of trace Molybdate ion from environmental water sample using inductive couple plasma atomic emission spectroscopy. The optimum $\mathrm{pH}$ value for sorption of the metal ion was 5 . The sorption capacity of functionalized resin is $3.1 \mathrm{mg} / \mathrm{g}$. The chelating sorbent can be reused for 20 cycles of sorptiondesorption without any significant change in sorption capacity. The best desorption of the metal ions from resin was obtained by $0.5 \mathrm{~mol} / \mathrm{L}$ nitric acid as eluting agent. The profile of molybdenum uptake on this sorbent reflects good accessibility of the chelating sites in the aniline- formaldehyde. Scatchard analysis revealed that the homogeneous binding sites were formed in the polymers. The equilibrium adsorption data of Molybdate ion modified resin were analyzed by five isotherm models such as Langmuir, Freundlich and Temkin. Langmuir isotherm parameters obtained from the four Langmuir linear equations by using linear method. Based on the Langmuir isotherm analysis, the monolayer adsorption capacity was determined to be $4.03 \mathrm{mg} / \mathrm{g}$ at $20^{\circ} \mathrm{C}$. The method was applied for molybdenum ions determination from river water sample.
\end{abstract}

Keywords: Adsorption; Aniline formaldehyde; Environmental measurement; Isotherm study; Solid phase extraction; Water samples

\section{INTRODUCTION}

Today most of the countries are facing drinking water problems and conditions are very severe especially in developing countries. The world is facing formidable challenges in meeting rising demands of clean water as the available supplies of freshwater are depleting due to 1) extended droughts, 2) population growth, 3) more stringent health based regulations, and 4) competing demands from a variety of users (US EPA, 1998; 1999; USBRSNL, 2003). Heavy metals (HMs) are considered as serious inorganic pollutants which cannot be destroyed. HMs are persistent $\triangle$ *Corresponding Author Email: hsidkalal@aeoi.org.ir
Tel: +9821 8800 3315; Fax: +9821 88003793 environmental contaminants and having a high enrichment factor and slow removal rate. They have toxic effects on human health, animals, plants and life in aquatic system (Karve and Rajgor, 2007; Arain et al., 2008; Dobaradaran et al., 2008; Atafar et al., 2010; Nouri et al., 2009; 2010). Recently, HMs pollution in natural water has been receiving tremendous attention. The toxic $\mathrm{HMs}$ such as $\mathrm{Mo}, \mathrm{Cd}$, and $\mathrm{Hg}$ are insignificant elements in human body and are capable of causing ecological risk to aquatic organisms. The toxic HMs could also gradually accumulate in human body through food chain and cause damage to human health (Chen et al., 2009). In view of the above facts, accurate 
determination of HMs has become increasing necessary to solve the problems connected with environmental water pollution.

However, the direct determination of these elements like molybdenum in real samples is a difficult task. The main restrictions come from the complexity of the matrix and the extremely low concentrations of analytes in those samples, which are often below the detection limits of available techniques (Camel, 2003; Lemos et al., 2006). Thus, highly sensitive and selective techniques are required. To solve this problem, preconcentration-separation procedures have been proposed. Preconcentration is a very important issue for achievement of low detection limits (Prabhakaran and Subramanian, 2003). There are many methods of preconcentration and separation such as liquid-liquid extraction (Saito et al., 2000) ion exchange techniques (Alguacil et al., 2005), coprecipitation (Prasad et al., 2006; Kagaya et al., 2006), membrane filter techniques (Karatepe et al., 2002), cloud point extraction (Sombra et al., 2001; Zhang et al., 2005). The pH dependence of Mo adsorption on chelating resins resembled that on oxides and clay minerals. Adsorption increased with increasing $\mathrm{pH}$ up to a peak near $\mathrm{pH} 6$ and then decreased with increasing $\mathrm{pH}$ above 4 (Goldberg et al., 1996). About the absorption of rare metals such as molybdenum by relevant absorbent (in ligand adsorption systems), the optimization of a ligand adsorption process requires an understanding of a factor that govern the interaction between ligands and immobilized metal ions on the matrix of the solid phase. Previous studies have shown that scatchard transformation (Scatchard, 1949) of the Langmuir equation offers more compact information about the charactristics of the isotherm in a simple manner. The shape of scatchard plot is related to the type of interaction of the ligand with the resin matrix and determined association binding constant of the ligand $\left(\mathrm{K}_{\mathrm{b}}\right)$.

The purpose of the present study is to indicate the feasibility of using aniline-formaldehyde as a solidphase extractant for preconcentration of trace molybdenum in environmental water samples. Trace molybdenum can be retained on the surface of anilineformaldehyde and then desorbed with $\mathrm{HNO}_{3} 0.5 \mathrm{~mol} / \mathrm{L}$ prior to determination by Inductive couple plasma atomic emission spectroscopy (ICP-AES). This proposed novel method has advantages of good accuracy and precision, high recovery and preconcentration factor. This research was carried out in the 2010 for determine Molybdate ions in river water (Gharah soo River, Kermanshah), Iran.

\section{MATERIALS AND METHODS}

Apparatus and Instrumentation

ICP-AES Varian, Vista-pro (Salt lake city, Australia) was used for measuring the concentration of Mo ion. The $\mathrm{pH}$ measurements were made with a Metrohm model 744 pH meter (Zofingen, Switzerland). Infrared spectra were recorded on a Jasco Fourier transform infrared spectrometer (FT-IR-410, Jasco Inc., Easton, Maryland) by the potassium bromide pellet method. Elemental analysis was carried out on a ThermoFinnigan (Milan, Italy) model Flash EA elemental analyzer.

\section{Reagents and solutions}

$\mathrm{HCl}, \mathrm{H}_{2} \mathrm{SO}_{4}, \mathrm{HNO}_{3}, \mathrm{NaNO}_{2}, \mathrm{NaOH}, \mathrm{NaCl}, \mathrm{CH}_{3} \mathrm{COOH}$, $\mathrm{CH}_{3} \mathrm{COONa}, \mathrm{NaH}_{2} \mathrm{PO}_{4}, \mathrm{Na}_{2} \mathrm{HPO}_{4}, \mathrm{~Pb}\left(\mathrm{NO}_{3}\right)_{2}$, $\mathrm{CuSO}_{4} \cdot 5 \mathrm{H}_{2} \mathrm{O}, \mathrm{Co}\left(\mathrm{NO}_{3}\right)_{2} \cdot 6 \mathrm{H}_{2} \mathrm{O}, \mathrm{Ni} \mathrm{SO}_{4} \cdot 6 \mathrm{H}_{2} \mathrm{O}, \mathrm{Zn}$ $\mathrm{SO}_{4} \cdot 7 \mathrm{H}_{2} \mathrm{O}, \mathrm{Al}\left(\mathrm{NO}_{3}\right)_{3}, \mathrm{Ag}\left(\mathrm{NO}_{3}\right), \mathrm{Mg}\left(\mathrm{NO}_{3}\right)_{2}, \mathrm{Ca}\left(\mathrm{NO}_{3}\right)_{2}$, $\mathrm{Ba}\left(\mathrm{NO}_{3}\right)_{2}, \mathrm{Na}_{2} \mathrm{MoO}_{4} \cdot 2 \mathrm{H}_{2} \mathrm{O}$, ethylenediaminetetraacetic acid (EDTA), $\mathrm{CH}_{3} \mathrm{COCH}_{3}, \mathrm{C}_{2} \mathrm{H}_{5} \mathrm{OH}, \mathrm{NH}_{3}$, urea and formaldehyde were products of Merck (Darmstadt, Germany). All the solutions were prepared in deionized water using analytical grade reagents.

The stock solution (500 mg/L) of Mo (II), were prepared by dissolving appropriate amounts of Mo $\left(\mathrm{NO}_{3}\right)_{2}$, in deionized water. $10 \mathrm{~mL}, 0.1 \mathrm{~mol} /$ Lacetic acid - acetate buffer (pH3 - 6.5), $0.01 \mathrm{~mol} / \mathrm{L}$ phosphate buffer ( $\mathrm{pH} 6.5$ - 9) were used to adjust the $\mathrm{pH}$ of the solutions, wherever suitable.

\section{Adsorbent}

Synthesis of aniline- formaldehyde

A mixture of $15 \mathrm{~mL}$ aniline and $15 \mathrm{~mL}$ formaldehyde was acidified with drop wise adding concentrated Hydrochloric acid ( $\mathrm{HCl})$. The mixture was blended till formation of a solid polymer. The polymer (anilineformaldehyde) was grinded and washed with warm water and acetone several times. The resin was dried at $60{ }^{\circ} \mathrm{C}$ and placed in a desiccator.

\section{Methodology and characterization of resin}

The polymer was characterized by Infrared (IR) and elemental analyses. The methodology used to synthesize polymer is summarized in Fig. 1. An IR 
spectrum of this chelating resin was run to verify the structure of aniline-formaldehyde aniline- formaldehyde: 3367.87 $(\mathrm{OH}), 1656.26(\mathrm{C}=\mathrm{O}), 1508$ (Aromatic $\mathrm{C}=\mathrm{C}$ ) and $1696(\mathrm{~N}=\mathrm{N}) / \mathrm{cm}$ (Fig. 2).

\section{Elemental analysis of adsorbent}

The elemental analysis for aniline-formaldehyde (found: C, 75.26; H, 5.93; N, $12.37 \%$; calculated for $\mathrm{C}_{7} \mathrm{NH}_{7}: \mathrm{C}, 80.00 ; \mathrm{H}, 6.6 ; \mathrm{N}, 13.3 \%$ ) confirm formation of the polymer.

\section{Batch adsorption experiments}

For the batch adsorption experiments, a sample solution $(50 \mathrm{~mL})$ containing $(60 \mu \mathrm{g} \mathrm{m} / \mathrm{L})$ of Molybdate was taken in a glass stopperd bottle and the $\mathrm{pH}$ was

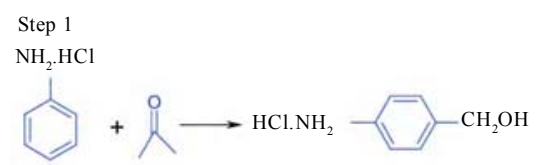

(a)

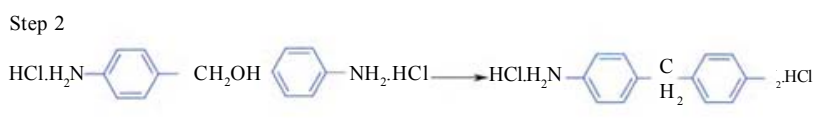

(b)

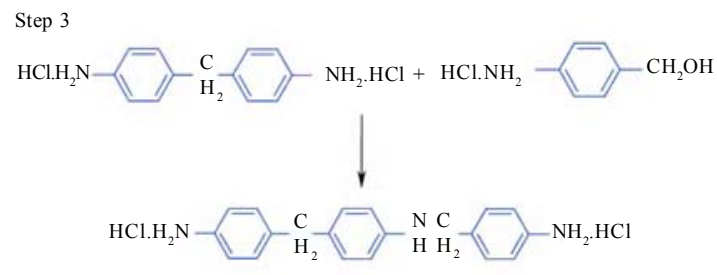

(c)

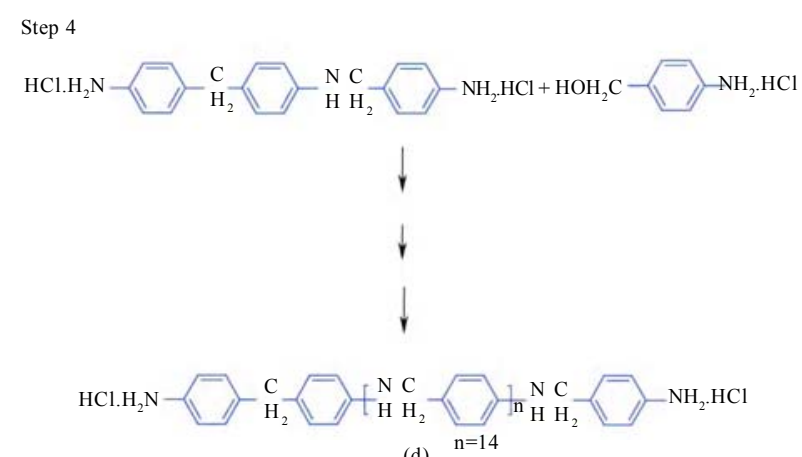

(d) $\mathrm{n}=14$

Fig. 1: The methodology of synthesize of aniline-formaldehyde adjusted to optimum value. The $0.2 \mathrm{~g}$ of anilineformaldehyde was weighed out and added to the bottle. The mixture was facilitated by agitation on a shaker for optimum time. The resin was filtered and adsorbed metal ion was eluted with $0.05 \mathrm{~mol} / \mathrm{LEDTA}$ $(10 \mathrm{~mL})$. The concentration of the metal ion in the eluant was determined by Inductively coupled plasma atomic emission spectroscopy (ICP-AES).

\section{Isotherm studies}

Adsorption isotherm experiments

Isotherm studies were carried out by adding a fixed amount of adsorbent $(0.2 \mathrm{~g})$ to a series of beakers filled with $50 \mathrm{ml}$ diluted solutions of Molybdate (10$100 \mu \mathrm{g} \mathrm{m} / \mathrm{L}$ ). The beakers were then sealed and placed in a water bath shaker and shaken at $200 \mathrm{rpm}$ with a required adsorbent time $(4 \mathrm{~h})$ at $20^{\circ} \mathrm{C}$ and optimum $\mathrm{pH}(6.5)$. $\mathrm{pH}$ adjustments have been done using 0.01 $\mathrm{mol} / \mathrm{L}$ acetate buffer. The beakers were then removed from the shaker and the final concentration of Molybdate in the solution was measured by ICP-AES.

\section{Adsorption isotherm modeling}

The Langmuir (Langmuir, 1916), Freundlich (Freundlich, 1906), Redlich-Peterson (Redlich and Peterson, 1959), Temkin (Ho and McKay, 2000) and Dubinin-Radushkevich (Hasany and Chaudhary, 1996) are the five most common isotherms (Table 1) that describe the distribution of a metal ion between a solid and a liquid phase (Mohanty et al., 2005; Mor et al.,

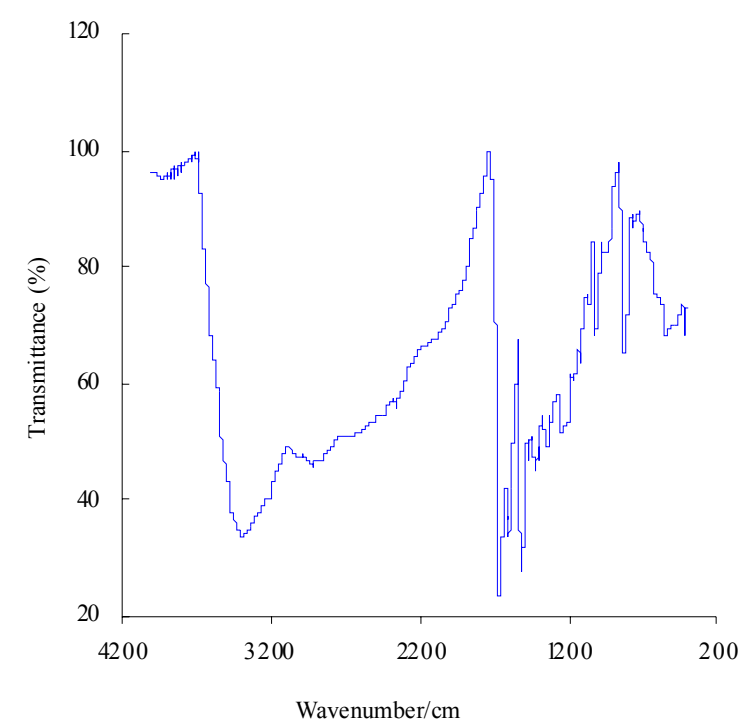

Fig. 2: FT-IR spectra of aniline-formaldehyde 
2007) and have been extensively used in the literature to model the uptake of various adsorbents (Chandra and Garg, 1992; Das et al., 2002; Ho, 2004; Abdel-Ghani et al., 2010; Malakootian et al., 2011).

The constants of isotherm models can be evaluated from the intercepts and the slopes of the linear plots of them as delineated in Table 1.

\section{RESULTS AND DISCUSSION}

Optimization of molybdenum adsorption's conditions Effect of initial $\mathrm{pH}$ on metal sorption

The degree metal sorption at different $\mathrm{pH}$ values was determined by batch equilibration technique. A set of solutions (the volume of each $50 \mathrm{~mL}$ ) containing $60 \mu \mathrm{g} . \mathrm{m} / \mathrm{L}$ of Molybdate was taken. Their $\mathrm{pH}$ values were adjusted in range 3-9 with $0.01 \mathrm{M}$ acetate and/or phosphate buffer solutions.0.2 g of anilineformaldehyde was added to each solution and the mixture was shaken for $4 \mathrm{~h}$. The optimum $\mathrm{pH}$ values for quantitative uptake of metal ions were ascertained by measuring the Molybdate content, by ICP-AES, in supernatant liquid and in the eluate obtained by desorbing the metal ion from aniline-formaldehyde with $0.5 \mathrm{M}$ nitric acid $(10 \mathrm{~mL})$. The optimum $\mathrm{pH}$ range for the sorption of the metal ion is shown in Fig. 3. The maximum recovery was $90 \%$ at $\mathrm{pH} 5$.

\section{Effect of elution agent}

The degree metal desorption at optimum $\mathrm{pH}$ values was determined by batch equilibration technique. Among of ethylenediaminetetraacetic acid (EDTA) 0.1 $\mathrm{mol} / \mathrm{L}, \mathrm{H}_{2} \mathrm{SO}_{4} 0.5 \mathrm{~mol} / \mathrm{L}$, and $\mathrm{HNO}_{3} 0.5 \mathrm{~mol} / \mathrm{L}$ as the elution agent, it was observed the $\mathrm{HNO}_{3} 0.5 \mathrm{~mol} / \mathrm{L}$ provided the best recovery. The result is shown in Table 2.

\section{Total sorption capacity}

The $0.2 \mathrm{~g}$ of aniline-formaldehyde was stirred for 4 h. with $50 \mathrm{~mL}$ solution containing $100 \mu \mathrm{g} \mathrm{m} / \mathrm{L}$ of Molybdate at optimum $\mathrm{pH}$ and $20^{\circ} \mathrm{C}$. The metal ion concentration in the supernatant liquid was estimated by ICP-AES.

The sorption capacity of the sorbent for the metal ion was ascertained from the difference between the

Table1: Isotherms and their linear forms (with linear transformations of the Langmuir isotherm)

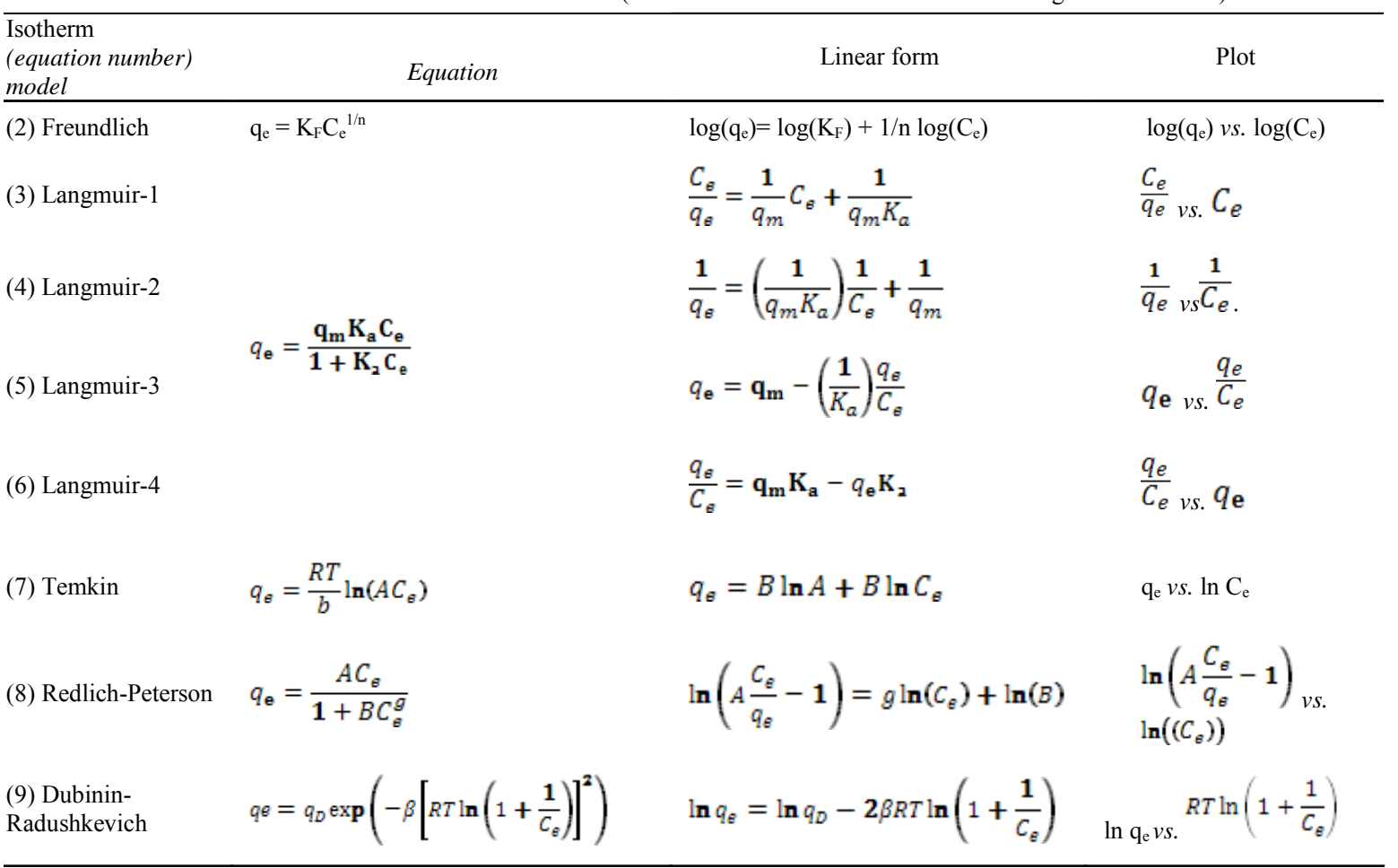


metal ion concentrations in solution before and after the sorption. The capacity of the resin for sorption of molybdenum ion was found $3.1 \mathrm{mg} / \mathrm{g}$. When the initial metal concentration rises, adsorption increases while the binding sites are not saturated.

\section{Stability and reusability}

The Molybdate was sorbed and desorbed on $0.2 \mathrm{~g}$ of the aniline-formaldehyde several times. It was found that sorption capacity of resin after 10 cycles of its equilibration with Mo ion, changes less than $10 \%$. Therefore, repeated use of the resin is feasible. The resin cartridge after loaded with samples can be readily regenerated with $0.5 \mathrm{~mol} / \mathrm{L} \mathrm{HNO}_{3}$. The sorption capacity of the resin stored for more than 6 months under ambient conditions has been found to be practically unchanged.

\section{Sorption time of molybdenum ions}

Optimum sorption time of molybdenum ions obtained with this procedure that aniline-formaldehyde $(0.2 \mathrm{~g})$ was shaken with $50 \mathrm{~mL}$ of solution containing $60 \mu \mathrm{g} \mathrm{m} / \mathrm{L}$ of Molybdate for different time $(5,15,30,45$,

Table 2: Effect of eluant on desorption of Molybdate ion

\begin{tabular}{cccc}
\hline Eluant & $0.1 \mathrm{M}$ EDTA & $0.5 \mathrm{H}_{2} \mathrm{SO}_{4}$ & $0.5 \mathrm{HNO}_{3}$ \\
\hline Recovery & $56 \%$ & $68 \%$ & $90 \%$ \\
\hline
\end{tabular}

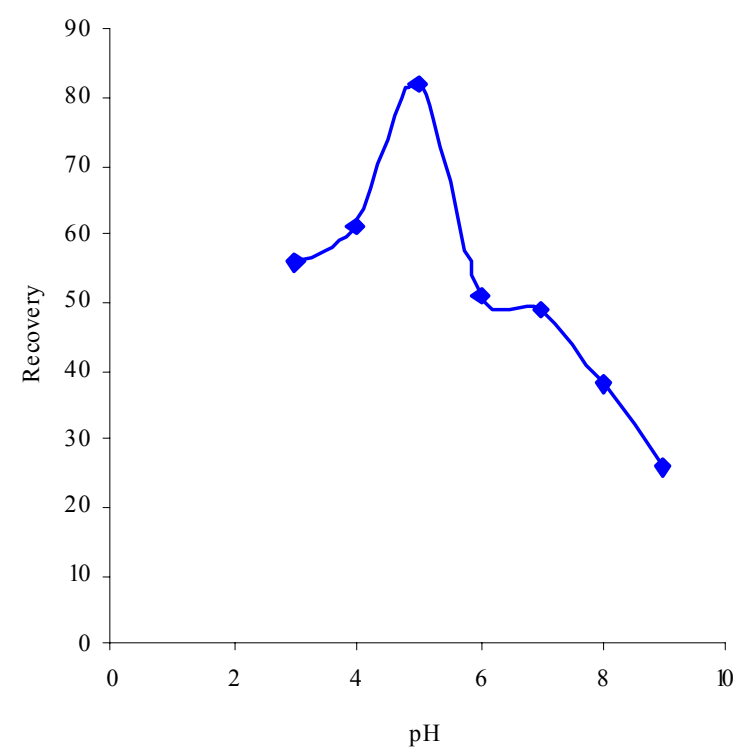

Fig. 3: Effect of $\mathrm{pH}$ sorption of Mo (II), onto aniline-formaldehyde
$60,90,120$, and $180 \mathrm{~min}$ ) under optimum $\mathrm{pH}$. After filtration of the sorbent, the concentration of molybdenum ions in solution was determined with ICPAES using the recommended batch method. The sorption as a function of contact time for all the metal ions is shown in Fig. 4. Less than 5 min shaking was required for $95 \%$ sorption. The profile of molybdenum uptake on this sorbent reflects good accessibility of the chelating sites in the aniline-formaldehyde.

\section{Adsorption isotherms}

Equilibrium relationships between sorbents and sorbates are described by adsorption isotherms which give the capacity of a sorbent for a sorbate. Isotherms can be obtained by examining batch reactions at fixed temperatures. The mean metal sorption coefficient $\left(\mathrm{q}_{\mathrm{e}}\right.$; in $\mathrm{mg} / \mathrm{g}$ sorbent) was calculated from the initial metal ion concentration $\left(\mathrm{C}_{0}\right.$; in $\left.\mathrm{mg} / \mathrm{dm}^{3}\right)$ and the final or equilibrium concentration $\left(\mathrm{C}_{\mathrm{e}}\right.$; in $\left.\mathrm{mg} / \mathrm{dm}^{3}\right)$ in every experiment as follows:

$q_{e}=\frac{v}{m}\left(C_{0_{-}} C_{e}\right)$

Where $v$ is the volume of initial metal ion solution used $\left(\mathrm{dm}^{3}\right)$ and $m$ is dry mass of adsorbent used $(\mathrm{g})$.

Sorption equilibra provides fundamental physicochemical data for evaluating the applicability of adsorption processes as a unit operation usually

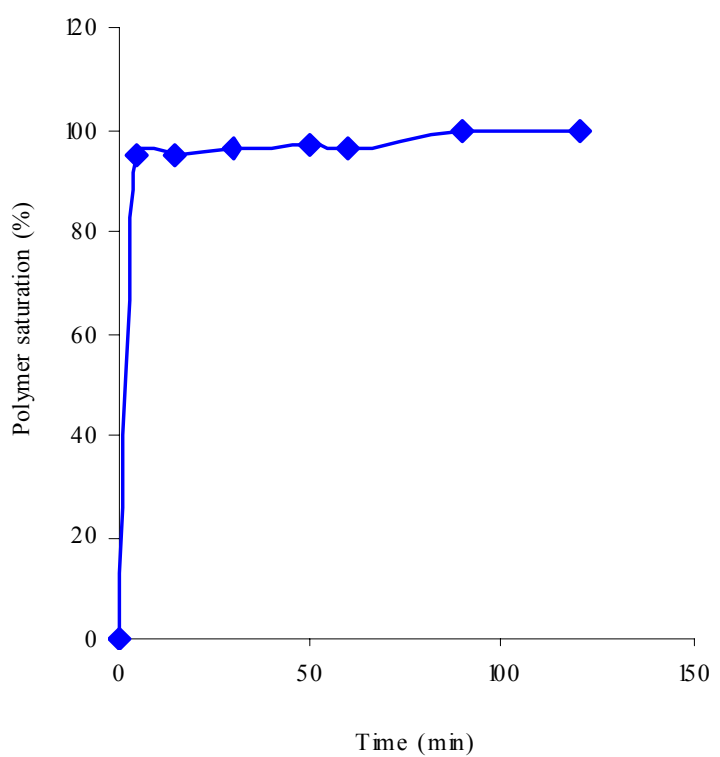

Fig 4: Kinetics of molybdenum sorption on aniline-formaldehyde 
described by isotherm models whose parameters express the surface properties and affinity of the sorbent, at a fixed temperature and $\mathrm{pH}$. Five isotherm models were used to fit the experimental data.

\section{Langmuir isotherm model}

Langmuir adsorption parameters are determined by transforming the Langmuir equation isotherm (Table 1) to a linear form. The isotherm can be made linear in at least four different ways. Depending on the linearization chosen shown in Table 1, different estimates are obtained for the values of the parameters. This occurs because, depending on the way the isotherm is linearized, the error distribution changes either for better or for worse (Kinniburgh, 1986). However, the best transformation has been extensively reported in the biochemical literature where equations analogous to the Langmuir isotherm are important for the description of the binding sites for the drugs and enzyme catalysis. Simple linear regression will result in different parameter estimates (Kinniburgh, 1986; Longhinotti et al., 1998).

The more popular linear forms used are Langmuir-1 and Langmuir-2, and the best fit is obtained using Langmuir-1 because of the minimal deviations from the fitted equation resulting in the best error distribution (Kinniburgh, 1986).

In this isotherm, $\mathrm{q}_{\max }$ is the maximum adsorption capacity corresponding to complete monolayer coverage on the surface $(\mathrm{mg} / \mathrm{g})$ and $\mathrm{K}_{\mathrm{L}}$ is the Langmuir constant (L/mg).

\section{Freundlich isotherm model}

This isotherm is an empirical equation employed to the described heterogeneous systems without lateral interactions, where in Freundlich equation, $K_{\mathrm{F}}$ and $1 / n$ are the Freundlich constants characteristics of the system, indicating the sorption maximum adsorption capacity and adsorption intensity, respectively, which is related to the affinity or binding strength (Davis, 2003).

\section{Temkin isotherm model}

This isotherm model was chosen to evaluate the adsorption potentials of the adsorbent for adsorbates. Temkin equation suggests a linear decrease of sorption energy as the degree of completion of the sorptional centers of an adsorbent is increased. In the linear form of Temkin equation (Table 1 ) $\mathrm{B}=\mathrm{RT} / \mathrm{b}$ and $\mathrm{b}$ is Temkin constant related to heat of sorption $(\mathrm{J} / \mathrm{mol})$. A is Temkin isotherm constant $(\mathrm{L} / \mathrm{g}), \mathrm{R}$ the gas constant $(8.314 \mathrm{~J} /$ $\mathrm{mol} / \mathrm{K})$ and $\mathrm{T}$ is the absolute temperature $(\mathrm{K})$.

\section{Redlich-Peterson isotherm model}

This isotherm contains three constants ( $A, B$ and $g$ ) and incorporates the features of the Langmuir and the Freundlich isotherms (Redlich and Peterson, 1959).

\section{Dubinin-Radushkevich isotherm model}

This isotherm was chosen to estimate the characteristics porosity of the adsorbent and the apparent energy of adsorption. In equation of this isotherm model, $B_{D}$ is related to the free energy of sorption per mole of the sorbate as it migrates to the surface of the adsorbent from infinite distance in the solution and $\mathrm{q}_{\mathrm{D}}$ is the Dubinin-Radushkevich isotherm constant related to the degree of sorbate sorption by the sorbent surface (Horsfall et al., 2004).

The different isotherms were tested for their ability to correlate with the experimental results by comparing theoretical plots of each isotherm with the experimental data for the adsorption of molybdenum ions on anilineformaldehyde at $293 \mathrm{~K}$ in Fig. 5. In this graph, the amount of molybdenum sorbed per unit mass of anilineformaldehyde, $q_{\mathrm{e}}$, is plotted against the concentration of molybdenum remaining in solution; $C_{\mathrm{e}}$ and the good fit of the Redlich-Peterson and Langmuir isotherms were not the same even when the coefficient of determinations was high for both isotherms. The coefficients of determination and constants for Freundlich, Temkin, Dubinin-Radushkevich, Redlich-Peterson and four Langmuir linear isotherms (Table 1) are given in Table 3. Langmuir-1 had the highest coefficients of determination compared with other Langmuir linear equations. It was observed that the coefficient of determination of Langmuir-1 is higher than that of Langmuir- 2 because of the minimal deviations from the fitted equation resulting in the best error distribution (Kinniburgh, 1986; Longhinotti et al., 1998). The coefficient of determination for both theoretical Langmuir-1 and Redlich-Peterson isotherms were higher than those obtained for Freundlich isotherm, indicating that the adsorption system is more likely monolayer coverage of the anilineformaldehyde surface by the Molybdate ions. These values of the coefficient of determinations, $R^{2}$, indicate that there is strong positive evidence that the sorption of molybdenum ions onto aniline-formaldehyde follows these isotherm models. The essential characteristics of 


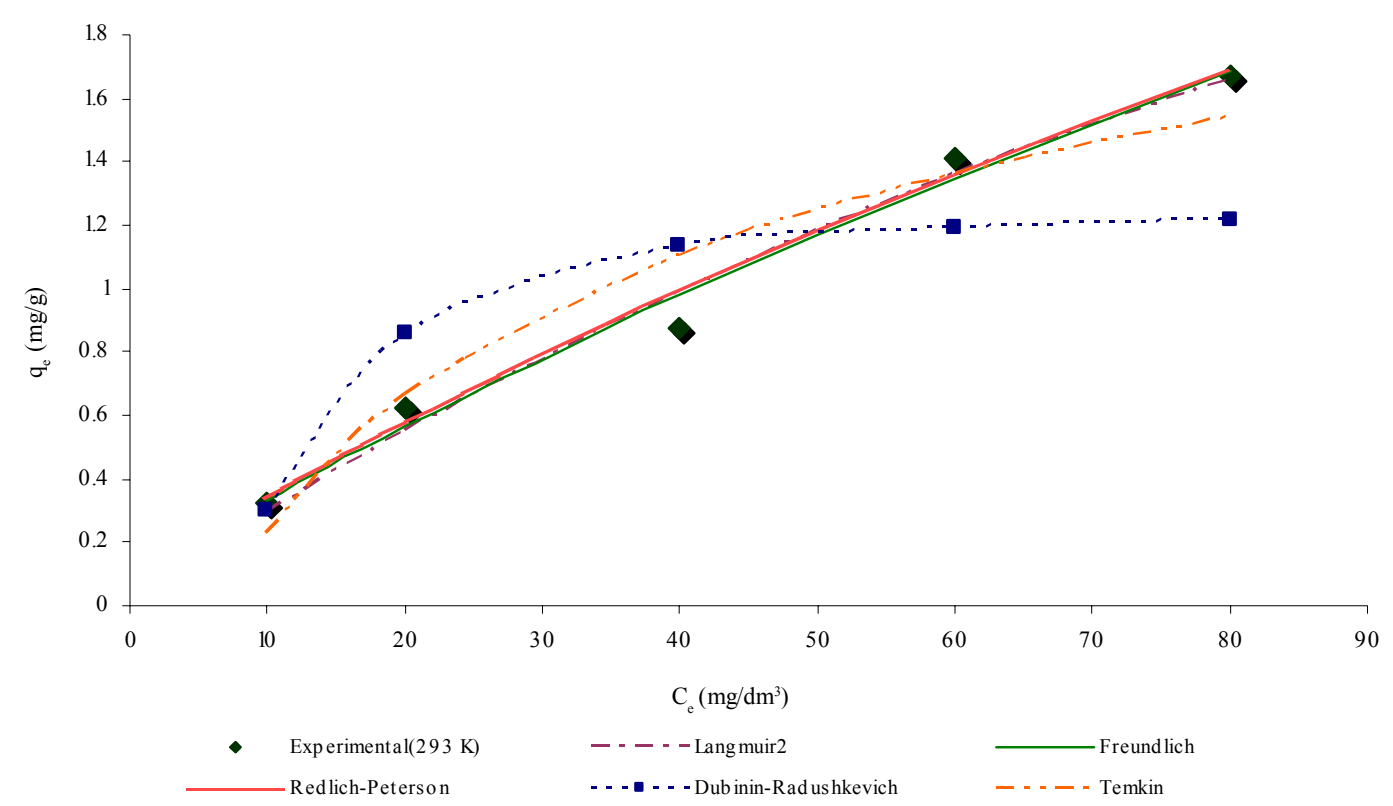

Fig. 5: Isotherms obtained using the linear method for the sorption of Mo (II) onto aniline-formaldehyde at a temperature of $293 \mathrm{~K}$

the Langmuir equation can be expressed in term of a dimensionless constant separation factor or equilibrium, $\mathrm{R}_{\mathrm{L}}$, defined as (Ahalya et al., 2005; Kagaya et al., 2006):

$R_{L}=1 /\left(1+K_{a} \cdot C_{0}\right)$

Where $\mathrm{K}$ is the Langmuir constant and $\mathrm{C}$ is the initial concentration of the metal ions. The $\mathrm{R}_{\mathrm{L}}$ value indicates

Table 3: Isotherm parameters obtained by using linear method

\begin{tabular}{llr}
\hline Best isotherm model & \multicolumn{1}{c}{ Parameters } & at T: $293 \mathrm{~K}$ \\
\hline & $\mathrm{R}^{2}$ & 0.9809 \\
Langmuir-2 & $\mathrm{q}_{\mathrm{m}} / \mathrm{mg} / \mathrm{g}$ & 5.1452 \\
& $\mathrm{~K}_{\mathrm{a}} / \mathrm{L} / \mathrm{mg}$ & 0.00598 \\
& $\mathrm{R}_{\mathrm{L}}$ & 0.0191 \\
& $\mathrm{R}^{2}$ & 0.985 \\
Freundlich & $\mathrm{n}$ & 1.2738 \\
& $\mathrm{~K}_{\mathrm{f}} /(\mathrm{mg} / \mathrm{g})(\mathrm{L} / \mathrm{mg})^{1 / \mathrm{n}}$ & 0.0541 \\
& $\mathrm{R}^{2}$ & 0.9329 \\
Temkin & $\mathrm{A} / \mathrm{L} / \mathrm{g}$ & 0.1436 \\
& $\mathrm{~B} / \mathrm{J} / \mathrm{mol}$ & 0.6316 \\
& $\mathrm{R}^{2}$ & 0.9847 \\
& & \\
Redlich-Peterson & $\mathrm{A} / \mathrm{dm} / \mathrm{g}$ & 27.6189 \\
& $\mathrm{~B} /\left(\mathrm{dm}^{3} / \mathrm{mg}\right)^{\mathrm{g}}$ & 478.18 \\
& $\mathrm{~g}$ & 0.2282 \\
Dubinin- & $\mathrm{R}^{2}$ & 0.8259 \\
Radushkevich & $\beta$ & $2.66 \mathrm{E}-05$ \\
& $\mathrm{E}$ & 137.1 \\
\hline
\end{tabular}

the shape of the isotherm. According to Mckay et al. (1982), $R_{L}$ values between 0 and 1 indicate favourable absorption. From this study, Table 3 shows the values of $R_{L}$ (for four Langmuir isotherms) are in the range of $0-1$ at optimum $\mathrm{pH}$ which confirms the favorable uptake of the Molybdate in agreement with Table 4.

If just the linear form of Langmuir-1 and 2 are used for comparison, Langmuir-1 and 2 were more suitable for the experimental data than was the Freundlich isotherm because of the higher value of the coefficient of determinations (Table 3). The Freundlich equation predicts that the Molybdate concentration on the adsorbent will increase so long as there is an increased in the Molybdate concentration in the liquid.

The Redlich-Peterson isotherm exhibited the highest coefficient of determinations, which produced a considerably better fit compared with the Temkin and Freundlich isotherms. It can be seen that the value of $g$ is close to unity, which means the isotherms are

Table 4: The parameter $R_{L}$ indicated the shape of isotherm

\begin{tabular}{ll}
\hline Value of $\mathrm{R}_{\mathrm{L}}$ & Type of isotherm \\
\hline $\mathrm{R}_{\mathrm{L}}>1$ & Unfavorable \\
$\mathrm{R}_{\mathrm{L}}=1$ & Linear \\
$0<\mathrm{R}_{\mathrm{L}}<1$ & Favorable \\
$\mathrm{R}_{\mathrm{L}}=0$ & Irreversible \\
\hline
\end{tabular}


approaching the Langmuir but not the Freundlich isotherm. It was observed that the coefficient of determination of Langmuir is higher than the other isotherms. It can be seen that the $g$ was unity, which means that the isotherms are approaching the Langmuir form and not the Freundlich isotherm. The result shows that the Langmuir isotherm best-fit the equilibrium data for adsorption of Molybdate on aniline-formaldehyde.

According to constant obtained for Freundlich isotherm in Table 3, $\mathrm{n}$ values between 1 and 10 represents beneficial adsorption (Kadirvelu and Namasivayam, 2000). Furthermore, Akgerman and Zardkoohi (Akgerman and Zardkoohi, 1996), state that the values of $\mathrm{k}_{\mathrm{F}}$ and $\mathrm{n}$ determine the steepness and curvature of the isotherm. The Freundlich equation frequently gives $n$ adequate description of adsorption data over a restricted range of concentration, even though it is not based on any theoretical background. Apart from a homogeneous surface, the Freundlich equation is also suitable for a highly heterogeneous surface and an adsorption isotherm lacking a plateau, indicating a multi-layer adsorption (Juang et al., 1996). The values of $1 / \mathrm{n}$, less than unity is an indication that significant adsorption takes place at low concentration but the increase in the amount adsorbed with concentration becomes less significant at higher concentration and vice versa (Hsisheng and ChienTo, 1998). Besides, the apparent energy (E) of adsorption from the Dubinin-Radushkevich isotherm, which was calculated using the following equation, is shown on the same Table 3 (Horsfall et al., 2004):

$E=\frac{1}{\sqrt{2 \beta}}$

The value of the apparent energy of adsorption shown on Table 3 depicts adsorption process (Horsfall et al., 2004). This means that the Dubinin-Radushkevich isotherm gave a very good fit to the adsorption process.

\section{Scatchard analysis}

Scatchard analysis was employed to further analyze the binding isotherms, which is an approximate model commonly used in SPE (Solid-phase extraction) characterization. The Scatchard equation can be expressed as: $\mathrm{Q} / \mathrm{C}=\left(\mathrm{Q}_{\max }-\mathrm{Q}\right) / \mathrm{K}_{\mathrm{d}}$, where $\mathrm{C}(\mu \mathrm{mol} / \mathrm{mL})$ is the equilibrium concentration of molybdenum; $\mathrm{Q}(\mu \mathrm{mol} /$ $\mathrm{g})$ is the equilibrium adsorption amount at each concentration; $\mathrm{Q}_{\max }(\mu \mathrm{mol} / \mathrm{g})$ is the maximum adsorption amount; and $\mathrm{K}_{\mathrm{d}}(\mu \mathrm{mol} / \mathrm{mL})$ is the equilibrium dissociation constant at binding sites (Abate and Masini, 2001; Peng et al., 2001). Fig. 6 shows the Scatchard plots of the binding of molybdenum to the resin. It is clear that the Scatchard plot for resin is a single straight line. The linear regression equation was $\mathrm{Q} / \mathrm{C}=-4.4783 \mathrm{Q}+28.582\left(\mathrm{R}^{2}=0.8131\right)$, suggesting that

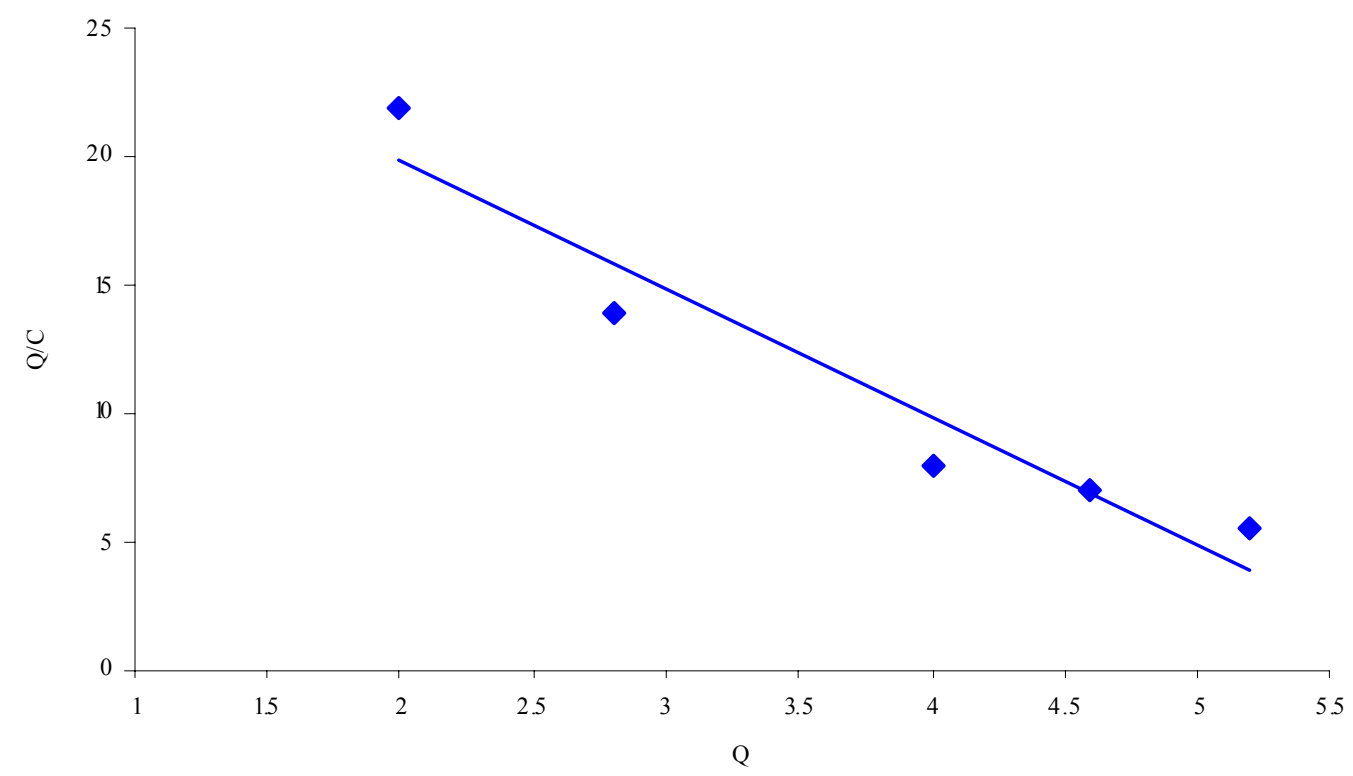

Fig. 6: Scatchard plots of Molybdate adsorption onto aniline- formaldehyde at $20{ }^{\circ} \mathrm{C}$ 
the homogeneous recognition sites for molybdenum were formed in the SPE resin. From the slope $\left(-4.4783\left(1 / \mathrm{K}_{\mathrm{d}}\right)\right)$ and intercept $\left(28.582\left(\mathrm{Q}_{\max } / \mathrm{K}_{\mathrm{d}}\right)\right), \mathrm{K}_{\mathrm{d}}$ and $\mathrm{Q}_{\max }$ for the affinity binding sites were calculated to be $0.2233 \mu \mathrm{mol} / \mathrm{mL}$ and $6.38 \mu \mathrm{mol} / \mathrm{g}$, respectively.

\section{Effect of foreign ions}

In order to evaluate the selectivity of the preconcentration system, the effect of some metal ions $(20 \mathrm{mg} / \mathrm{L})$ on the sorption behavior of Mo ion (concentration $20 \mathrm{mg} / \mathrm{L}$ ) was investigated. The extraction percentage $(\mathrm{E} \%)$ and the distribution ratio (D) was calculated from the following equations:

$$
\begin{aligned}
& Q=\left(C_{0}-C_{e}\right) V / W \\
& E=\left(C_{0}-C_{e}\right) / C_{0} \\
& D=Q / C_{e}
\end{aligned}
$$

Where Q represents the adsorption capacity $(\mathrm{mg} /$ $\mathrm{g}), \mathrm{C}_{0}$ and $\mathrm{C}_{\mathrm{e}}$ represent the initial and equilibrium concentration of Mo ion $(\mu \mathrm{g} / \mathrm{mL}), \mathrm{W}$ is the mass sorbent $(\mathrm{g}), \mathrm{V}$ is the volume of metal ion solution (L), E
$\%$ is the extraction percentage and $\mathrm{D}$ is the distribution ratio $(\mathrm{mL} / \mathrm{g})$. The result was shown in Table 5 . This table indicates that the most effective ions on adsorption of Mo ion on aniline- formaldehyde are $\mathrm{Cu}$ (II). The effects of other mentioned foreign ions at given concentrations are negligible. The adsorption of Mo ion on the aniline-formaldehyde in presence of all mentioned ions (with each ion having the concentration of $20 \mathrm{mg} / \mathrm{L}$ ) shows that the Mo ion can be determined quantitatively in the environmental samples.

\section{Application of method}

Aniline-formaldehyde was used to preconcentrate and determine Molybdate ions in river water (Gharahsoo River) Kermanshah, Iran. The pH of water sample was adjusted to the optimum $\mathrm{pH}$. Solid phase extraction with aniline- formaldehyde coupled with ICP-AES was applied to determination of Molybdate in water sample. Since no Mo ion was detected in the water sample, $100 \mathrm{~mL}$ water sample was spiked with $0.02,0.04$ and $0.06 \mathrm{mg}$ of Mo ion before subjecting it to the recommended procedure.

\begin{tabular}{|c|c|c|c|c|}
\hline Interfering & A & $\mathrm{L}(\%)$ & $\mathrm{E}(\%)$ & $\mathrm{D}$ \\
\hline ------ & 3.9 & 0.0 & 19.5 & 0.24 \\
\hline Ni (II) & 3.6 & 7.7 & 18.0 & 0.22 \\
\hline Co (II) & 3.6 & 7.7 & 18.0 & 0.22 \\
\hline Zn (II) & 3.6 & 7.7 & 18.0 & 0.22 \\
\hline Cd (II) & 3.6 & 7.7 & 18.0 & 0.22 \\
\hline $\mathrm{K}(\mathrm{I})$ & 3.9 & 0.0 & 19.5 & 0.24 \\
\hline $\mathrm{Na}(\mathrm{I})$ & 3.9 & 0.0 & 19.5 & 0.24 \\
\hline $\mathrm{Cu}$ (II) & 3.3 & 15.4 & 16.5 & 0.20 \\
\hline Mixed above ion & 3.2 & 17.9 & 16.0 & 0.19 \\
\hline
\end{tabular}
The results are shown in Table 6 . These results

Table 5: Effect of other ions on sorption

\begin{tabular}{|c|c|c|c|}
\hline Analyte & (I) & (II) & (III) \\
\hline Sample (without spiking of Mo (II) & ND & ND & ND \\
\hline Added Mo (II) $(\mu \mathrm{g} / \mathrm{mL})$ & 0.2 & 0.4 & 0.6 \\
\hline Found Mo (II), after preconcentration $(\mu \mathrm{g} / \mathrm{mL})$ & 1.7 & 3.3 & 5.0 \\
\hline Preconcentration factor & 10 & 10 & 10 \\
\hline Recovery $(\%)$ & 85 & 82.5 & 83.3 \\
\hline Standard deviation & 0.091 & 0.165 & 0.227 \\
\hline Relative standard deviation $(\%)^{a}$ & 5.35 & 5.00 & 4.54 \\
\hline
\end{tabular}

A: Amount of adsorbed Mo (II) (mg/L), L: Loss adsorption (\%), E: extraction percentage (\%) and D: distribution ratio

Table 6: Results obtained for Mo ion determination in water sample: (I), (II) and (III)

a: For three determinations; ND: Not Detected 
demonstrate the applicability of the procedure for Mo determination in samples with high recovery $(>82 \%)$.

\section{Analytical performance of the proposed system}

Seven replicate determinations of $0.5 \mathrm{mg} / \mathrm{L}$ Molybdate solutions gave a relative standard deviation of $6.52 \%$. The limit of detection corresponding to three times the blank standard deviation was found to be $1.3 \mu \mathrm{g} / \mathrm{L}$. The limit of quantification corresponding to ten times the blank standard deviation was found to be $4.3 \mu \mathrm{g} / \mathrm{L}$. The regression equation (after preconcentration) was $\mathrm{A}=0.836 \mathrm{C}_{\mathrm{Mo}}+0.0037\left(\mathrm{R}^{2}=0.9674\right)$ and the conventional regression equation was $\mathrm{A}=0.557 \mathrm{C}_{\mathrm{Mo}}$ $+0.0043\left(\mathrm{R}^{2}=0.9594\right)$. The enrichment factor, defined as the ratio of the slopes of the linear section of the calibration graphs before and after the preconcentration, was 1.5 . The theoretical preconcentration factor, calculated as the ratio of the sample $(100 \mathrm{~mL})$ to the eluent volume $(10 \mathrm{~mL})$, was 10 .

\section{CONCLUSION}

A new chelating resin shows higher adsorption selectivity for Molybdate ions and adsorbed ions can be readily desorbed from the resin by $10 \mathrm{~mL}$ of $0.5 \mathrm{~mol} / \mathrm{L} \mathrm{HNO}_{3}$. The synthesis of the resin is simple and economical. The resin has a good potential for enrichment of trace amount of Molybdate from large sample volumes. The resins also present the advantage of high adsorption capacity, good reusability and high chemical stability. The sorption of the investigated metal ions increases by increasing the contact time. Based on the Langmuir isotherm analysis, the monolayer adsorption capacity was determined to be $4.03(\mathrm{mg} / \mathrm{g})$ at $20^{\circ} \mathrm{C}$. The $R_{L}$ values showed that the aniline-formaldehyde was favorable for the adsorption of Mo (II). Preconcentration by this resin combined with ICPAES can be applied to the determination of trace molybdenum ions in water and the mineral reference sample with satisfactory results.

\section{ACKNOWLEDGEMENTS}

The authors gratefully acknowledge the support of this work by Department of Chemistry, NFRS, Nuclear Science and Technology Institute. The authors would like to thank Dr. M.H. Mousazadeh for his helpful comments.

\section{REFERENCES}

Abate, G.; Masini, J. C., (2001). Acid-basic and complexation properties of a sedimentary humic acid. a study on the barra bonita reservoir of tietê river, so paulo state, Brazil. J. Braz. Chem. Soc., 12 (1), 109-116 (8 pages).

Abdel-Ghani, N. T.; Hegazy, A. K.; El-Chaghaby, G. A., (2009). Typha domingensis leaf powder for decontamination of aluminium, iron, zinc and lead: Biosorption kinetics and equilibrium modeling. Int. J. Environ. Sci. Tech., 6 (2), 243-248 (6 pages).

Ahalya, N.; Kanamadi, R. D.; Ramachandra, T. V., (2005). Biosorption of chromium (VI) from aqueous solutions by the husk of Bengal gram (Cicer arientinum). Electronic J. Biotechnol., 8 (3), 258-264 (6 pages).

Akgerman, A.; Zardkoohi, M., (1996). Adsorption of phenolic compounds on Fly Ash. J. Chem. Eng. Data., 41(2), 185-191 (6 pages).

Alguacil, F. J.; Adeva, P.; Alonso, M., (2005). Processing of residual gold (III) solutions via ion exchange. Gold Bull., 38 (1), 9-13 (4 pages)

Arain, M. B.; Kazi, T. G.; Jamali, M. K.; Afridi, H. I.; Jalbani, N.; Baig, J. A., (2008). Speciation of heavy metals in sediment by conventional, ultrasound and microwave assisted single extraction: A comparison with modified sequential extraction procedure. J. Hazard. Mater., 154 (1-3), 998-1006 (8 pages).

Atafar, Z.; Mesdaghinia, A.; Nouri, J.; Homaee, M.; Yunesian, M., (2010). Effect of fertilizer application on soil heavy metal concentration. Environ. Monitor. Assess., 160 (14), 83-89 (7 Pages).

Camel, V., (2003). Solid phase extraction of trace elements. Spectrochim. Acta B, 58, 1177-1233 (56 pages).

Chandra, P.; Garg, P., (1992). Adsorption and toxicity of chromium and cadmium in Limnanthemum Cristatum Griseb. Sci. Total Environ., 125, 175-183 (8 pages).

Chen, D.; Hu, B.; Huang, C., (2009). Chitosan modified ordered mesoporous silica as micro-column packing materials for on-line flow injection-inductively coupled plasma optical emission spectrometry determination of trace heavy metals in environmental water samples. Talanta, 78 (2), $491-497$ (6 pages).

Das, D. D.; Mahapatra, R.; Pradhan, J.; Das, S. N.; Thakur, R. S., (2002). Removal of Cr(VI) from aqueous solution using activated cow dung carbon. J. Colloid Interf. Sci., 232 (920), 235- 240 (5 pages).

Davis, T. A.; Volesky, B.; Mucci, A., (2003). A review of the biochemistry of heavy metal biosorption by brown algae. Water Res., 37 (18), 4311 - 4330 (19 pages).

Dobaradaran, S.; Mahvi, A. H.; Dehdashti, S.; Abadi, D. R. V., (2008). Drinking water fluoride and child dental caries in Dashtestan, Iran. Fluoride, 41 (3) 220-226 (7 pages). Freundlich, H. M. F., (1906). Über die adsorption in lösungen. Z. Phys. Chem-Frankfurt, 57A, 385-470 (86 pages).

Goldberg, S.; Forster, H. S.; Godfrey, C. L., (1996). Molybdenum adsorption on oxides, clay minerals and soils. Soil Sci. Soc. Am. J., 60 (2), 425-432 (8 pages).

Hasany, S. M.; Chaudhary, M. H., (1996). Sorption potential 
of Haro river sand for the removal of antimony from acidic aqueous solution. Appl. Rad. Isot., 47 (4), $467-$ 471 ( 6 pages).

Ho, Y. S., (2004). Selection of optimum sorption isotherm. Carbon, 42 (10), 2115-2116 (17 pages).

Ho, Y. S., McKay, G., (2000). The kinetics of sorption of divalent metal ions onto sphagnum moss peat. Water Res., 34 (3), 735-742 (7 pages).

Horsfall, M.; Spiff, A. I.; Abia, A. A., (2004). Studies on the influence of mercaptoacetic acid (MAA) modification of cassava (Manihot sculenta Cranz) waste biomass on the adsorption of $\mathrm{Cu} 2+$ and $\mathrm{Cd} 2+$ from aqueous solution. Bull. Korean Chem. Soc., 25 (7), 969-976 (7 pages).

Hsisheng, T., Chien-To, H., (1998). Influence of surface characteristics on liquid-phase adsorption of phenol by activated carbons prepared from Bituminous. Coal. Ind. Eng. Chem. Res., 39 (9), 3618-3624 (6 pages).

Juang, R. S; Wu, F. C.; Tseng, R. L., (1996). Adsorption isotherms of phenolic compounds from aqueous solutions onto activated carbon fibers. J. Chem. Eng. Data, 41 (3), 487-492 (5 pages).

Kadirvelu, K.; Namasivayam, C., (2000). Agricutural byproduct as metal adsorbent: Sorption of lead (II) from aqueous solution onto coirpith carbon. Environ. Tech., 21 (10), 1091-1097 (6 pages).

Kagaya, S.; Sagisaka, T.; Miwa, S.; Morioka, K.; Hasegawa, K., (2006). Rapid coprecipitation technique with hybrid hydroxide system using ytterbium(III), Gallium(III) and magnesium(III) for simultaneous concentration of 13 elements in concentrated salt solution prior to their inductively coupled plasma atomic emission spectrometric determination. Bull. Chem. Soc. Jpn., 79 (5), 717-724 (7 pages).

Karatepe, A. U.; Soylak, M.; Elci, L., (2002). Separation/ preconcentration of $\mathrm{Cu}(\mathrm{II}), \mathrm{Fe}(\mathrm{III}), \mathrm{Pb}(\mathrm{II}), \mathrm{Co}(\mathrm{II})$ and $\mathrm{Cr}(\mathrm{III})$ in aqueous samples on cellulose nitrate membrane filter and their determination by atomic absorption spectrometry. Anal. Lett., 35, 1561-1574 (11 pages).

Karve, M.; Rajgor, R. V., (2007). Solid phase extraction of lead on octadecyl bonded silica membrane disk modified with Cyanex302 and determination by flame atomic absorption spectrometry. J. Hazard. Mater., 141 (3), 607613 (6 pages).

Kinniburgh, D. G., (1986). General purpose adsorption isotherms. Environ. Sci. Tech., 20 (9), 895-904 (9 pages).

Langmuir, I., (1916). The constitution and fundamental properties of solids and liquids. J. Am. Chem. Soc., 38 (11), 2221-2295 (75 pages).

Lemos, V. A.; Silva, D. G.; Carvalho, A. L.; Santana, D. A.; Dos Santos, G. N.; Dos Passos, A. S., (2006). Synthesis of amberlite XAD-2-PC resin for preconcentration and determination of trace elements in food samples by flame atomic absorption spectrometry. Microchem. J., 84 (12), 14-21 (7 pages).

Longhinotti, E.; Pozza, F.; Furlan, L.; Sanchez, M. D. N. D.; Klug, M.; Laranjeira, M. C. M.; Favere, V. T., (1998). Adsorption of anionic dyes on the biopolymer chitin. J. Braz. Chem. Soc., 9 (5), 435-440 (5 pages).

Malakootian, M.; Yousefi, N.; Fatehizadeh, A., (2011). Survey efficiency of electrocoagulation on nitrate removal from aqueous solution. Int. J. Environ. Sci. Tech. 8 (1), 107-114 (8 pages)

Mckay, G.; Blair, H. S.; Gardener, J. R., (1982). Adsorption of dyes on chitin. I. Equilibrium studies. J. Appl. Polym. Sci., 27 (8), 3043-3057 (14 pages).

Mohanty, K.; Mousam, J.; Meikap, B. C.; Biswas, M. N., (2005). Removal of $\mathrm{Cr}(\mathrm{VI})$ from dilute aqueous solution by activated carbon developed from Terminalia Arjuna nuts activated with zinc chloride. Chem. Eng. Sci., 60 (11), 3049-3059 (10 pages).

Mor, S.; Ravindra, K.; Bishnoi, N. R., (2007). Adsorption of chromium from aqueous solution by activated alumina and activated charcoal. Biores. Tech., 98 (11), 954-957 (3 pages).

Nouri, J.; Khorasani, N.; Lorestani, B.; Karami, M.; Hassani, A.H.; Yousefi, N. (2009). Accumulation of heavy metals in soil and uptake by plant species with phytoremediation potential. Environ. Earth Sci., 59 (2), 315-323 (9 pages).

Nouri, J.; Lorestani, B.; Yousefi, N.; Khorasani, N.; Hasani, A. H.; Seif, S.; Cheraghi, M. (2011). Phytoremediation potential of native plants grown in the vicinity of Ahangaran lead-zinc mine (Hamedan, Iran). Environ. Earth Sci., 62 (3), 639-644 (6 pages).

Peng, H.; Zhang, Y., Zhang, J., Xie, Q., Nie, L., Yao, S., (2001) Development of a thickness shear mode acoustic sensor basedon an electrosynthesized molecularly imprinted polymer usingan underivatized amino acid as the template. Analyst, 126, 189-194 (6 pages).

Prabhakaran, D.; Subramanian, M. S., (2003). A column system for the selective extraction of U(VI) and Th(IV) using a new chelating sorbent. Talanta, 61 (4), 423-430 ( 7 pages).

Prasad, K.; Gopikrishna, P.; Kala, R.; Rao, T. P.; Naidu, G. R. K., (2006). Solid phase extraction vis-à-vis coprecipitation preconcentration of cadmium and lead from soils onto 5,7-dibromoquinoline-8-ol embedded benzophenone and determination by FAAS. Talanta, 69 (4), 938-945 (7pages).

Redlich, O.; Peterson, D. L., (1959). A useful adsorption isotherm. J. Phys. Chem., 63 (9), 1024 (1 page).

Saito, K.; Taninaka, I.; Yamamoto, Y.; Murakami, S.; Muromatsu, A., (2000). Liquid-liquid extraction of platinum(II) with cyclic tetrathioethers. Talanta, 51 (5), 913-919 (6 pages).

Scatchard, G., (1949). The attractions of protein for small molecules and ions. Ann. N. Y. Acad. Sci., 51 (4),660672 (13 pages).

Sombra, L.; Luconi, M.; Silva, M. F.; Olsina, R. A.; Fernandez, L., (2001). Spectrophotometric determination of trace aluminium content in parenteral solutions by combined cloud point preconcentration-flow injection analysis. Analyst, 126 (7), 1172-1176 (4 pages).

USBRSNL (2003). Desalination and water purification technology roadmap a report of the executive committee Water Purification, US Bureau of Reclamation and Sandia National Laboratories.

US EPA, (1998). Microbial and disinfection by-product rules. US Environmental Protection Agency, Federal Register, 
63, 69389-69476.

US EPA, (1999). Alternative disinfectants and oxidants guidance manual. US Environmental Protection Agency, EPA Office of Water Report, 815-R: 99-104 (6 pages).
Zhang, Y.; Luo, W. H.; Li, H., (2005). Determination of trace cobalt in water samples by graphite furnace atomic absorption spectrometry after cloud point. Spectrosc. Spect. Anal., 25 (4), 576-578 (3 pages).

\section{AUTHOR (S) BIOSKETCHES}

Sid Kalal, H., Ph.D., Assistant Professor, Waste Management Department, NFRS, Nuclear Science and Technology Institute, Tehran, Iran. Email: hsidkalal@aeoi.org.ir

Ahmad Panahi, H., Ph.D., Assistant Professor, Department of Chemistry, Islamic Azad University, Central Tehran Branch, Iran. Email: Panahi20002000@yahoo.com

Faramarzi, N., Msc. candidate, Department of Chemistry, Islamic Azad University, Central Tehran Branch, Iran. Email: apadana0098@yahoo.com

Moniri, E., Ph.D., Assistant Professor, Department of Chemistry, Islamic Azad University, Varamin (Pishva) Branch, Iran. Email: Moniri30003000@yahoo.com

Naeemy, A., M.Sc. candidate, Department of Chemistry, Faculty of Science, K.N. Toosi University of Technology. Email: anaeemy@yahoo.com

Hoveidi, H., Ph.D., Assistant Professor, Department of Environmental Management, Graduate Faculty of Environment, University of Tehran, Iran. Email: hoveidi@ut.ac.ir

Abhari, A., Laboratory technician, NFRS, Nuclear Science and Technology Institute, Tehran, Iran. Email: mehdiasgari2002@yahoo.com

\section{How to cite this article: (Harvard style)}

Sid Kalal, H.; Ahmad Panahi, H.; Faramarzi, N.; Moniri, E.; Naeemy, A.; Hoveidi, H.; Abhari, A., (2011). A New chelating resin for preconcentration and determination of molybdenum by inductive couple plasma atomic emission spectroscopy. Int. J. Environ. Sci. Tech., 8 (3), 501-512. 